2010 (according to excavation materials № 3)] // Novi doslidzhennia pam’iatok kozatskoi doby v Ukraini. 2011. Vyp. 20. S. 71-79. [in Ukrainian]

Teslenko, 2014 - Teslenko Y.B. Odna yz honcharnykh tradytsyi Tavryky XIV-XV vv. (keramyka hruppy YuhoZapadnoho Kryma) [One of the pottery traditions of Taurica XIV-XV centuries. (ceramics of the South-West Crimea group)] // Ystoryia y arkheolohyia Kryma. Vyp. 1. Symferopol. 2014. S. 495-512, 541-560. [in Russian]

Tykhomyrov, 1979 - Tykhomyrov M.N. «Spysok russkykh horodov dalnykh y blyzhnykh» [«List of Russian cities far and near»] // Russkoe letopysanye. M.,1979. S. 83-137. [in Russian]

Toichkin, 2014 - Toichkin D.V. Bulavy y pernachi na terenakh Ukrainy: zbroia ta symvol vlady [Maces and feathers on the territory of Ukraine: weapons and symbols of power] // Istoriia davnoi zbroi. Doslidzhennia 2014: zb. nauk. pr. Instytut istorii Ukrainy NAN Ukrainy; Natsionalnyi viiskovo-istorychnyi muzei Ukrainy. Kyiv: In-t istorii Ukrainy NANU. 2014. S. 227-241. [in Ukrainian]

Chernaia, 1998 - Chernaia E.D. Kollektsyia polyvnoi keramyky Khersonskoho kraevedcheskoho muzeia [Collection of glazed ceramics of the Kherson Museum of Local Lore] // Ystoryko-kulturnbe sviazy Prychernomoria y Sredyzemnomoria X-XVIII vv. Po materialam polyvnoi keramyky. Tezysы dokladov nauchnoi konferentsyy. Symferopol, 1998. S. 186-189. [in Russian]

Shlapak, 2004 - Shlapak M. Belhorod-Dnestrovskaia krepost. Yssledovanye srednevekovoho oboronnoho zodchestva [Belgorod-Dnestrovskaya fortress. Study of medieval defense architecture]. Kyshynev, 2004. 237 s. [in Russian]

Evarnickij, 1898 - Evarnickij D.I. Vol'nosti zaporozhskih kozakov [Liberties of the Zaporozhye Cossacks]. SPb., 1898. 427 s. [in Russian]

Yavornytskyi, 1990 - Yavornytskyi D.I. Istoriia zaporozkykh kozakiv. U 3-kh t [History of the Zaporozhian Cossacks. In 3 volumes]. T. 1 / Peredmova V.A. Smoliia; Red. kol.: P.S. Sokhan (holova), V.A. Smolii (zast. holovy), V.H. Sarbei, H.Ya. Serhiienko, M.M. Shubravska (vidp. sekr.). AN Ukrainskoi RSR. Arkheohrafichna komisiia, Instytut istorii. K.: Naukova dumka, 1990. 596 s. [in Ukrainian]

Urbanavićiene, 1995 - Urbanaviciene S. Dictarų kapininas // Lietuvos archeologija. 1995. T. 11. S. 169-206. [In Lithuanian]

УДК 94(477)323.32"1991/2020"

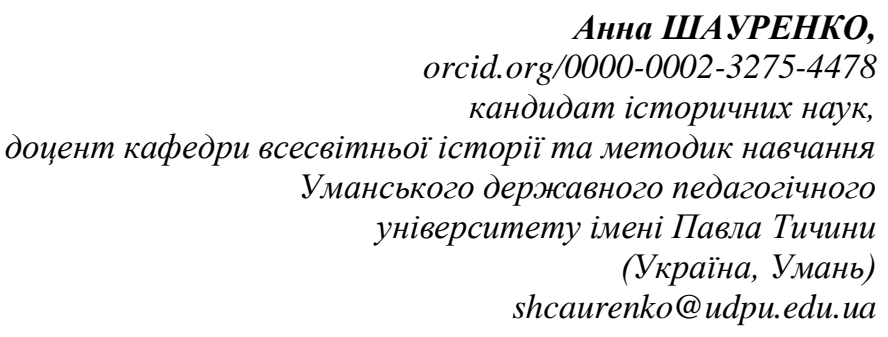

\title{
ДОБРОБУТ СЕЛЯН У ПОСТРАДЯНСЬКИЙ ПЕРІОД
}

У статті розглянуто особливості добробуту сільського населення у пострадянський період. Акцентується увага на забезпеченості населення необхідним для життя матеріальними благам. Насамперед, продуктами харчування, промисловими товарами, послугами та умовами, щчо задовольняють певну потребу людини $i$ відповідають ї̈ інтересам. У не найкращуму стані перебувала сочіальна сфера, комунальне господарство і медицина. Кризові явища, якими супроводжувалися трансформаційні процеси в економіці, завдали відчутних збитків матеріальному забезпеченню селян. За результатами зібраних матеріалів доведено, щзо економічна криза, швидкі темпи інфляиії, проблема дефіцитуу товарів, затримка коштів для виплати заробітної плати в 90-х рр. ХХ ст. ускладнювали матеріальне становище сільського населення України. Ключові слова. побут, селянство, матеріальний добробут, інфраструктура, медицина, культура, освіта.

Anna SHAURENKO

Candidate of Historical Sciences, Associate Docent of World History and methods of Teaching Uman State Pedagogical University Paul Tychiny

(Ukraine, Uman) shcaurenko@udpu.edu.ua 


\section{PEASANTS' WELFARE IN A POST-SOVIET PERIOD}

In the realities of modern Ukraine an urgent task is based on a significant improvement of the population's welfare, the creation of appropriate living conditions for it. Therefore, a critical use of the experience of previous years in ensuring the living conditions of a rural population is of scientific and practical importance.

The article deals with the peculiarities of rural population's welfare in a post-Soviet period. The emphasis is placed on providing the population with necessary life material goods. First of all, with food, industrial goods, services and conditions meeting a certain human need and corresponding to its interests.

A national income of the state was reduced, there was currency depreciation. Growing inflation rates significantly influenced a living standard of Ukrainian citizen. A decline in population's income led to a considerable decline in a consumption level. The low quantitative and qualitative level of production of consumer goods and rising prices for most goods led to an increase in the deficit. Due to lack of funds, wage arrears and low assortment of products in shops, peasants were forced to provide themselves almost entirely with food and basic necessities, so subsistence farming and land became the main source of income.

A social sphere, public utilities and medicine were in a catastrophic state. Among the negative social manifestations caused by the decline in agricultural production and the transformation of public sector farms into privately owned agricultural enterprises was the high level of unemployment of the rural population - unemployment.

Crisis phenomena, accompanying the transformation processes in economics, caused a considerable damage to peasants' material security. The result was a deterioration in rural services. In many cases, peasants lost the opportunity to meet basic necessities, including health care, education and upbringing of children, which reduced the quality of life of the rural population, nullified the attractiveness of the rural environment, and pushed young people away from the countryside.

According to the collected materials, it has been found out that in a post-Soviet period positive changes in peasants' welfare were slow. It has been proved that the economic crisis, rapid inflation rates, a shortage of goods, the delay of funds for the payment of wages in the 90's of the XX century complicated a financial situation of a rural population of Ukraine. However, the dynamics of changes may be traced, but the state failed to fully improve a material well-being of peasants in the first decade of its independence.

Key words. Everyday life, peasantry, material well-being, infrastructure, medicine, culture, education.

Постановка проблеми. Історичні реалії, що склалися в Україні 3 проголошенням державної незалежності, відкривали нові можливості вибору більш якісних шляхів облаштування суспільного життя. Ринкове середовище вимагало пріоритетного розвитку соціальної сфери, в якій реалізовуються соціально-економічні інтереси різних груп населення, відносини суспільства i людини, задовольняються матеріальні та духовні потреби, створюються належні умови життєдіяльності. В 90 -х роках XX ст. на території України селянство залишалося однією 3 найчисельніших та найважливіших ланок соціальної стратифікації країни, що й спричинило поступове зростання наукових інтересів до цієї верстви населення, зокрема до історії їх буденного життя.

Аналіз досліджень. Питання добробуту сільського населення України після виходу зі складу СРСР неодноразово піднімали в науковій літературі. Однак у більшості праць вони висвітлені не як самостійна проблема, а принагідно - в контексті загальної історії, при вивченні паралельних історичних явищ. Наприклад, соціально-побутовим потребам мешканців села, рівню та можливостям їх задоволення присвячені роботи І. Прокопи, який досліджував село 3 економічної точки зору (Прокопа, 1996). Значний фактичний матеріал узагальнено у книзі Л. Ковпак «Соціально-побутові умови життя населення України в другій половині ХХ ст. (1945-2000рр.)» (Ковпак, 2003), де на основі залучення великого обсягу нових архівних документів досліджено соціально-побутові умови життя населення України у взаємозв'язку 3 історичними подіями, що відбулися у другій половині XX ст. Широку 
панораму фактів і подій історії України після здобуття незалежності подає також Г. Касьянов (Касьянов, 2008).

Здійснюючи огляд історіографії нашої проблеми, варто вказати на появу у 2006 році праці «Історія українського селянства» у двох томах (Смолій, 2006), де подано характеристику різноманітних політичних і соціально-економічних трансформацій історії селянства від давнини до наших днів.

3-поміж праць вітчизняних фахівців виокремимо дослідження М. Ігнатенко, яка аналізувала соціально-економічні зміни в українському селі упродовж 1991-2008 pp. (Ігнатенко, 2009). Ї̈̈ науковий доробок став першим кроком у вивченні місця і ролі українського села в процесах державотворення.

Мета статті полягає в тому, щоб на основі вивчення матеріалів, опублікованих статистичних джерел, наукової літератури, провести комплексний аналіз процесів, які характеризують добробут сільського населення у пострадянський період.

Виклад основного матеріалу. Серед основних чинників, які визначають рівень розвитку соціальної сфери села, важливе місце займає матеріальний добробут селян. Він характеризує забезпеченість населення необхідними для життя матеріальними благами, насамперед продуктами харчування, промисловими товарами, послугами, та умовами, що задовольняють певну потребу людини і відповідають іiі інтересам.

Економічна криза, різкий спад сільськогосподарського виробництва, високі темпи інфляції, що загострились в період проголошення незалежності України, призвели до погіршення матеріального добробуту сільського населення, істотного зниження всіх його параметрів.

Такий стан соціальної сфери села був зумовлений також значним падінням обсягів будівництва об'єктів соціального призначення на селі. Введення в дію житла наприкінці 90-х рр. ХХ ст. зменшилось порівняно 3 початком цього десятиліття в 3 рази, лікарень і загальноосвітніх шкіл - у 4-6 разів, амбулаторно-поліклінічних закладів, дитячих садків і клубів - у 13-55 paziв.

У 1999 р. в сільській місцевості залишилось всього близько чверті підприємств побутового обслуговування населення (порівняно 31990 р.); мережа підприємств роздрібної торгівлі скоротилася майже наполовину, дитячих дошкільних закладів - на чверть, закладів культури - на 15\%. Закривалися дільничні лікарні (чи перепрофільовувались в амбулаторії), будинки-інтернати, школи. Лише в 1998 р. на селі закрито 38 лікарень, 57 фельдшерсько-акушерських пунктів. 51 школу, 384 дошкільних заклади освіти. Через відсутність належного фінансування протягом 1996-2001 рр. кількість шкіл зменшилася на 316, дошкільних навчальних закладів - на 2 тис, дільничних лікарень - на 475, клубів та будинків культури - на 2 тис; 315 сіл із населенням понад 500 осіб не мали закладів охорони здоров'я (Балановська, 2000: 275).

Наслідком цього ставало погіршення обслуговування населення на селі. У багатьох випадках селяни втрачали можливість задовольняти найнеобхідніші життєві потреби, в тому числі в охороні здоров’я, навчанні й вихованні дітей, а 
це знижувало якість життя сільського населення, зводило нанівець привабливість сільського життєвого середовища, відштовхувало від села молодь.

Скорочення мережі і погіршення роботи медичних установ на селі, зниження доступності міських закладів через нерегулярність руху і дорожнечу пасажирського транспорту, подорожчання лікування призвели до того, що селяни стали рідше звертатись по медичну допомогу. Це стало однією з причин їх високої смертності.

Головна причина цього - фінансові нестатки сільськогосподарських підприємств, недостатність державних капітальних вкладень, неспроможність селян вести будівництво житла власним коштом і недостатність державної підтримки соціальної інфраструктури села (включаючи допомогу індивідуальним забудовникам). У той же час значними були обсяги незавершеного будівництва по об'єктах соціальної сфери - так звані довгобуди. Недобудованими стояли 1100 шкіл, 620 дошкільних закладів, 24 тис. км. газових мереж.

Поряд 3 негативами, в сільській соціальній інфраструктурі в 90-ті рр. минулого століття відбувалися й деякі позитивні процеси. Вони стосувалися здебільшого зростання оснащеності сіл інженерними мережами і, відповідно, підвищення рівня інженерного облаштування житлового фонду. Так, у 1990 р. водопровідні мережі мали 4.6 тис. сільських населених пунктів, а в 1998 р. - 6,6 тис; газопровідні - відповідно 2,4 тис. і 7,3 тис. Хоча навіть при зазначеному зростанні рівень забезпеченості сільського житлового фонду централізованим водопостачанням становив 17 \%, а сітьовим (природним) газом - $27 \%$, каналізацією лише - 12 \%. Порівняно з європейськими країнами це були все ж невисокі показники комфортності життєвого середовища (Завальнюк, 2004: 242).

Складною залишалася ситуація із забезпеченням сільського населення питною водою. Жителі 420 сіл користувалися тільки привізною водою, ще у більш ніж 800 селах використовували привізну воду поряд з іншими джерелами водопостачання. Більшість селян (понад 75 \%) вживали воду з місцевих джерел - шахтних і мілкотрубних колодязів, копанок тощо, i аналізи даної води на хімічну і бактеріологічну забрудненість показували, що більша іï частина не відповідала санітарно-епідеміологічним нормам.

До того ж у селах електропостачання часто відключаюся, такі традиційні енергоносії, як вугілля і скраплений газ, сильно подорожчали. Майже 50 \% сільських вулиць не були заасфальтованими і не мали освітлення. Понад 10 тис. сільських населених пунктів не мали зупинок громадського транспорту, 4,2 тис. сіл знаходилися від зупинок на відстані понад 3 кілометри. Більшість сільських доріг перебувала в занедбаному стані, потребувала ремонту і облаштування (Статистичний щорічник України, 2010).

Серед негативних соціальних проявів, спричинених спадом аграрного виробництва i трансформацією господарств суспільного сектору в приватновласницькі сільськогосподарські підприємства, став високий рівень трудової незайнятості сільського населення - тобто безробіття. Внаслідок 
скорочення сільськогосподарського виробництва чисельність працівників сільгосппідприємств протягом 1991-2001 рр. зменшилася майже вдвічі, частина 3 них жила із присадибних ділянок. У 2001 р. згідно з даними Держкомстату України, із 7,8 млн. працездатних осіб, які мешкали в сільській місцевості, лише в особистих селянських господарствах було зайнято 1,9 млн., ще майже 1,6 млн. працездатного сільського населення були незайнятими або ж зайнятими в домашньому господарстві (Статистичний збірник, 1997).

Значно погіршилось харчування селян, зокрема м'ясом, рибою i рибопродуктами, хоча на нього витрачається в середньому майже 70\% сукупного доходу сільських сімей. Незбалансоване харчування негативно позначилось на людському організмі, значно погіршився стан здоров'я та знизилась трудова активність людини (Саблук, 2002: 7).

Існувало кілька способів забезпечення сімей продуктами харчування. Основним серед них було придбання продовольчих товарів у торговельній мережі. Дещо менше значення 3-поміж усіх видів домашніх господарств мало самозабезпечення продовольством шляхом його виробництва в особистих господарствах, а також шляхом одержання натуральної допомоги від рідних i близьких. За останнє десятиліття тут відбулися значні структурні зрушення.

В Україні відбувався інтенсивний процес переміщення сільськогосподарського виробництва в особисті господарства. Поряд із цим спостерігаються значні зміни в структурі споживання продовольства. Самозабезпечення сільських сімей продуктами харчування 3 власних господарств $є$ результатом не лише переміщення в них основної частини сільськогосподарського виробництва, а й розв'язання проблеми продовольчого забезпечення в умовах нестачі грошових доходів.

На межі XXI ст. питома вага спожитих м'яса i м'ясопродуктів, вироблених в особистих господарствах населення, становила 25,2 \%, молока i молочних продуктів - 46,2, яєць - 41,4, риби і рибопродуктів - 2,8, цукру - 3,5, картоплі - 70,8, овочів і баштанних - 46,2, фруктів, ягід, горіхів і винограду 35,3, хліба та хлібопродуктів - 10,0\%. Ці показники в міських і сільських поселеннях різнилися між собою в багато разів. У сільській місцевості найвища питома вага самозабезпечення виробленою в особистих господарствах продукцією спостерігалася в таких продуктах харчування, як картопля (98 \%), яйця (93,7%), молоко і молочні продукти (82,7 \%) (Баховський, 2003: 83).

Темпи зростання цін на продовольчі й непродовольчі товари і послуги мали визначальний вплив на динаміку реальної заробітної плати як одного 3 основних джерел грошових доходів населення. Індекс інфляції в країні протягом 1997-2001 pp. становив 210,3\%. Номінальна середньомісячна заробітна плата в грудні 2001 р. порівняно з груднем 1997 р. зросла на 154,9 \%.

Під дією обох чинників середньомісячний розмір реальної заробітної плати зріс, проте зростання рівня реальної заробітної плати, в тому числі й сільського населення, зовсім не означало підвищення ऑiі купівельної спроможності по всьому колу продовольчих товарів. У грудні 2001 р. на одну середньомісячну заробітну плату можна було придбати більше, ніж у грудні 1997 р.: ковбаси вареної та сосисок - на 23,9 \%, вершкового масла - на 34,3, 
маргарину - на 33,6, сметани - на 37, рису - на 36,7, гречаної крупи - на 50,4 \% тощо. Разом із тим багатьох видів продовольчих товарів на кінець досліджуваного періоду можна було придбати значно менше, ніж на його початку, зокрема яловичини і свинини - майже наполовину, риби мороженої, олії, цукру тощо (Рівень життя населення України, 2006).

Зниження реальних доходів сільських жителів зменшує частку його витрат на оплату різноманітних послуг. Безплатні послуги стають платними, що обмежує доступ до них більшості населення. Серед окремих видів платного обслуговування сільських жителів найбільше витрачається коштів на житловокомунальні, транспортні послуги, оранку землі тощо.

Основу платного обслуговування населення в сільській місцевості становлять: житлово-комунальні послуги (66,1\%), побутові $(14,3 \%)$, санаторно-курортні та оздоровчі $(5 \%)$, зв'язку $(14,3 \%)$, пасажирського транспорту $(4,9 \%)$, культури $(0,4 \%)$, виховання та освіти $(0,6 \%)$ та ін.

Характерною особливістю сільського способу життя було ведення особистого підсобного господарства (ОПГ). Воно справляє величезний вплив на всі сторони сільського життя: визначає режим праці і відпочинку сільської родини, спосіб задоволення потреби в продуктах харчування, тип житла, планування садиби і навіть тип забудови сіл; опосередковано формує ставлення до навколишнього середовища, праці взагалі і в сільському господарстві зокрема; впливає на вибір молоддю професії і майбутнього місця проживання тощо. Практично кожна сільська сім'я веде ОПГ.

За даними обстеження 1996 р., при наявності в селах 6.3 млн. житлових будинків чисельність ОПГ сільського населення становила 6,5 млн. Крім того, в селах налічувалося ще й понад 250 тис. ОПГ міського населення. У 90-ті pp. загалом зросли: кількість ОПГ, площа їх землекористування, поголів'я більшості видів худоби; дещо збільшився загальний обсяг вироблюваної продукції. Як складова життєвого середовища, особисте підсобне господарство сільських жителів $\epsilon$ для них одночасно середовищем і трудової, і споживчої діяльності (остання стосується передусім задоволення потреби в їжі). Можна виділити 4 найголовніші функції ОПГ: забезпечення власних потреб сільського населення в продуктах харчування: участь у формуванні товарних продовольчих ресурсів та сукупного доходу сімей: трудове виховання підростаючого покоління, особливо коли йдеться про колективне садівництво i городництво (Балановська, 2000: 269).

За даними статистики сімейних бюджетів, частка ОПГ у забезпеченні сільських сімей продуктами харчування становила: м'ясом і м'ясопродуктами близько $80 \%$, молоком і молокопродуктами, а також овочами і баштанними понад $85 \%$, картоплею - майже $95 \%$, фруктами і ягодами - $72 \%$, яйцями $100 \%$. У 90-ті рр. ХХ ст. відбулося деяке збільшення частки ОПГ в балансі продовольчих ресурсів селян. Якщо враховувати, що такі продовольчі товари, як хліб та хлібопродукти, олія, цукор, копченості, масло, сир, хоч i не надходять безпосередньо із підсобних господарств, але виготовляються 3 сировини, яка виробляється в цих господарствах, то стає очевидним, що ОПГ залишалося основою продовольчого забезпечення селян. 3 викладеного нібито 
випливає висновок про посилення в 90-ті pp. ХX ст. функції ОПГ щодо забезпечення власних потреб сільського населення в продуктах харчування.

Проте такий висновок був би не зовсім правильним. Адже в цей час суттєво знизився рівень споживання селянами більшості тих продуктів, які вони самі виробляли. Порівняння відповідних показників за роками також свідчило про погіршення харчування сільських жителів. Так, у подібних групах сімей споживалося м'яса і м'ясопродуктів у 1991 р. 56,7 кг, а в 1998 р. - 35,1. молока і молокопродуктів відповідно 344 і 294 кг і т. д. (Смолій, 2006: 567).

Таким чином, у 90-х рр. знизився рівень використання селянами особистих підсобних господарств для власного продовольчого забезпечення. При одночасному розширенні даного сектору сільськогосподарського виробництва це означало посилення товарної функції ОПГ, однак це був часто вимушений захід, до якого спонукав селян економічний спад, незайнятість, безгрошів'я. Обмежуючи себе в харчуванні, селяни привозили на ринок вироблену в особистих підсобних господарствах продукцію, щоб здобути у такий спосіб кошти для придбання необхідних товарів: палива, одягу, взуття, шкільних підручників, ліків тощо.

Проте роль ОПГ у збільшенні сукупних доходів селян і підвищенні їх зайнятості мала й деякі негативні прояви: зокрема використання важкої ручної праці, недосконалі форми збуту вирощеної сільгосппродукції (переважно самотужки, на ринках - централізованих і навіть стихійних) та ін. Протягом тижня сукупний робочий час у селян був перебільшений на чверть, а вільного часу було в 1,4 рази менше порівняно з робітниками і службовцями у містах, що не сприяло фізичному й духовному розвиткові селянина як особистості.

Сільське населення не мало можливості придбати найнеобхідніше предмети господарювання та домашнього вжитку, паливо, ліки, транспортні засоби, інструменти та реманент для ведення присадибного і домашнього господарювання.

Висновки. Після проголошення незалежності позитивні зміни в добробуті селян відбувалися повільно. Економічна криза, швидкі темпи інфляції, проблема дефіциту товарів, затримка коштів для виплати заробітної плати в 90 - х pp. XX ст. ускладнювали матеріальне становище сільського населення України. Відбулася руйнація системи колективного господарства та з'явилися такі нові явища, як приватизація землі та зародження бізнесу. Проте динаміка змін прослідковується, і це можна побачити, якщо ознайомитися 3 історією повсякдення сільських жителів у більш детальному розрізі, наприклад, крізь призму ведення ОПГ чи в розрізі окремих регіонів.

Тим не менш, вивчення перевіреного життям історичного досвіду сприяє усвідомленню минулого, допомагає успішно розв'язати практичні завдання економічного та соціального будівництва на сучасному етапі.

\section{СПИСОК ВИКОРИСТАНИХ ДЖЕРЕЛ І ЛІТЕРАТУРИ}

Балановська, 2000 - Балановська Т. Сільський сектор України на рубежі тисячоліть. Т.1. : Потенціал сільського сектора. Київ : Інститут економіки НАН України, 2000. 396 с.

Баховський, 2003 - Баховський В. Ціни на продовольчі товари і рівень життя населення // Економіка АПК. 2003. №12. C. 81-87. 
Державна служба статистики України, 1992-2001 - Державна служба статистики України: статистична інформація. URL: http://www.ukrstat.gov.ua/ (дата звернення 25.11.2021).

Завальнюк, 2004 - Завальнюк О., Рибак І. Новітня аграрна історія України. Камянець-Подільський : АбеткаHOBA, 2004. $288 \mathrm{c}$.

Ігнатенко, 2009 - Ігнатенко М. Українське селянство: побутова та культурно-освітня сфера (1991-1997 рр.) // Освіта, наука і культура на Поділлі: зб. наукових працьь, присвячений 90-річчю Кам'янецької доби УНР. Кам'янець-Подільський : Опіюм, 2009. Т. 13. С. 386-394.

Касьянов, 2008 - Касьянов Г. Україна 1999 - 2007 : нариси новітньої історії. Київ : Наш час, 2008. 432 с.

Ковпак, 2003 - Ковпак Л. В. Соціально-побутові умови життя населення України в другій половині ХХ ст. (1945-2000рр.) Київ : Інститут історії України НАН України, 2003. 250 с.

Прокопа, 1996. - Прокопа I. В. Соціальна інфраструктура села: формування нового механізму розвитку. Київ : НАН України, Інститут економіки, 1996. 172 с.

Рівень життя населення України, 2006 - Державний комітет статистики України: рівень життя населення України. URL: https://idss.org.ua/monografii/riven_juttya_naselennya\%20krainu.pdf (дата звернення 25.11.2021).

Рівень життя населення України, 2006 - Рівень життя населення України / за ред. Л. М. Черенько. Київ : ТОВ «Видавництво «Консультант», 2006. 428 с.

Саблук, 2002 - Саблука П. Т., Орлатий М. К. Матеріальний добробут сільських жителів. Київ : Інститут аграрної економіки УААН, 2002. 369 с.

Смолій, 2006 - Смолій В. А. Історія українського селянства : нариси в 2 т. Київ : Наукова думка, 2006. Т. 2. 653 c.

Статистичний збірник, 1997 - Соціально-економічне становище сільських населених пунктів України : статистичний збірник. Київ : Держкомстат України, 1997. 175 с.

Статистичний щорічник України, 2010 - Статистичний щорічник України 2009 рік / за ред. О. Г. Осауленка. Київ : Держкомстат України, 2010. 567 с.

\section{REFERENCES}

Bakhovskyi, 2003 - Bakhovskyi V. Tsiny na prodovolchi tovary i riven zhyttia naselennia [Food prices and living standards]. // Ekonomika APK. 2003. №12 S.81-87. [in Ukrainian].

Balanovska, 2000 - Balanovska T. Silskyi sektor Ukrainy na rubezhi tysiacholit [Ukraine's rural sector at the turn of the millennium]. T.1. : Potentsial silskoho sektora. Kyiv : Instytut ekonomiky NAN Ukrainy, 2000. 396 s. [in Ukrainian].

Derzhavna sluzhba statystyky Ukrainy, 1992-2001 - Derzhavna sluzhba statystyky Ukrainy: statystychna informatsiia [State Statistics Service of Ukraine: statistical information]. URL: http://www.ukrstat.gov.ua/ (data zvernennia 25.11.2021) [in Ukrainian].

Ihnatenko, 2009 - Ihnatenko M. Ukrainske selianstvo: pobutova ta kulturno-osvitnia sfera (1991-1997 rr.) [Ukrainian peasantry: household and cultural-educational sphere (1991-1997)]. // Osvita, nauka i kultura na Podilli: zb. naukovykh prats, prysviachenyi 90-richchiu Kamianetskoi doby UNR. Kamianets-Podilskyi : Opiium, 2009. T. 13. S. 386-394. [in Ukrainian].

Kasianov, 2008 - Kasianov H. Ukraina 1999 - 2007: narysy novitnoi istorii [Ukraine 1999-2007: Essays on Recent History].Kyiv : Nash chas, 2008. 432 s. [in Ukrainian].

Kovpak, 2003 - Kovpak L. V. Sotsialno-pobutovi umovy zhyttia naselennia Ukrainy v druhii polovyni KhKh st. (1945$2000 \mathrm{rr}$.) [Socio-living conditions of the population of Ukraine in the second half of the twentieth century (1945-2000)] Kyiv : Instytut istorii Ukrainy NAN Ukrainy, 2003. 250 s. [in Ukrainian].

Prokopa, 1996. - Prokopa I. V. Sotsialna infrastruktura sela: formuvannia novoho mekhanizmu rozvytku [Social infrastructure of the village: formation of a new mechanism of development].

Kyiv : NAN Ukrainy, Instytut ekonomiky, 1996. 172 s. [in Ukrainian].

Riven zhyttia naselennia Ukrainy, 2006 - Riven zhyttia naselennia Ukrainy [The standard of living of the population of Ukraine]. / za red. L. M. Cherenko. Kyiv : TOV «Vydavnytstvo «Konsultant», 2006. 428 s. [in Ukrainian].

Riven zhyttia naselennia Ukrainy, 2006 Derzhavnyi komitet statystyky Ukrainy: riven zhyttia naselennia Ukrainy [State Statistics Committee of Ukraine: living standards of the population of Ukraine]. URL: https://idss.org.ua/monografii/riven_juttya_naselennya\%20krainu.pdf （data zvernennia 25.11.2021) [in Ukrainian].

Sabluk, 2002 - Sabluka P. T., Orlatyi M. K. Materialnyi dobrobut silskykh zhyteliv [Material well-being of rural residents]. Kyiv : Instytut ahrarnoi ekonomiky UAAN, 2002. 369 s. [in Ukrainian].

Smolii, 2006 - Smolii V. A. Istoriia ukrainskoho selianstva: narysy: v 2 t. [History of the Ukrainian peasantry: essays in 2 volumes]. Kyiv : Naukova dumka, 2006. T. 2. 653 s. [in Ukrainian].

Statystychnyi shchorichnyk Ukrainy, 2010 - Statystychnyi shchorichnyk Ukrainy 2009 rik [Statistical Yearbook of Ukraine 2009]. / za red. O.H. Osaulenka. Kyiv : Derzhkomstat Ukrainy, 2010. 567 s. [in Ukrainian].

Statystychnyi zbirnyk, 1997 - Sotsialno-ekonomichne stanovyshche silskykh naselenykh punktiv Ukrainy: statystychnyi zbirnyk [Socio-economic situation of rural settlements of Ukraine: statistical collection]. Kyiv : Derzhkomstat Ukrainy, 1997. 175 s. [in Ukrainian].

Zavalniuk, 2004 - Zavalniuk O., Rybak I. Novitnia ahrarna istoriia Ukrainy [Recent agrarian history of Ukraine]. Kamianets-Podilskyi : Abetka-NOVA, 2004. 288 s. [in Ukrainian]. 